\title{
Mal, religión y saber: un enfoque relacional-integral que cuestiona diez paradigmas dominantes
}

\author{
Alberto J. GIL IBÁÑEZ \\ Instituto de Ciencias de las Religiones. Universidad Complutense de Madrid \\ agiba_ue@yahoo.es
}

\begin{abstract}
RESUMEN
El actual discurso social sobre el mal es obsoleto e ineficaz. Vivimos bajo presupuestos cognitivos (parcialmente) fallidos que se resisten a sucumbir porque están en juego necesidades psicológicas unidas a un determinado concepto del ser humano, de Dios (o de lo que se esconde tras esta idea para los ateos) y de la realidad. Este artículo trata de desarrollar un nuevo enfoque del problema-enigma del mal que pone en cuestión diez paradigmas dominantes, planteando la necesidad de reconocer su existencia (en torno al concepto de exceso) como requisito para plantarle cara como única opción moral, la de luchar con todas las armas disponibles, incluido un saber que aspira a relacionar e integrar diversos saberes en torno a un único objetivo: derrotar el mal o al menos intentarlo.
\end{abstract}

Palabras clave: Mal, religión, saber, enfoque interdisciplinar.

\section{Evil, Religion and Knowledge: a Relational-Integration Approach that Challenges Ten Dominant Paradigms}

\begin{abstract}
The present social discourse about evil is obsolete and inefficient. We live under (partially) failed cognitive assumptions due to psychological needs connected to a concrete concept of human being, God (o what this idea means for atheists) and reality. This article develops a new approach to evil that challenges ten dominant paradigms by arguing the need to recognize evil's existence, around the concept of excess, as a requisite to face it as the only moral option. We must fight with all the tools at our disposal, included the relation and integration of different types of knowledge with a common goal in mind: defeating evil o attempting it.
\end{abstract}

Keywords: Evil, religion, knowledge, interdisciplinary approach.

SUMARIO: 1.Cómo superar un discurso sobre el mal obsoleto e ineficaz: el enfoque relacional-integral. 2. Concepto y existencia del mal: cuatro paradigmas en cuestión. 2.1. Hay que excluir al mal del discurso social por incomprensible. 2.2. El mal no tiene existencia propia, es una mera ausencia del bien o algo irrelevante. 2.3. O «todo es blanco o negro» (maniqueísmo-dualismo) o «todo vale lo mismo» (relativismo-panteísmo). 2.4. El mal no puede ser identificado ni definido. 3. Origen y causas del mal: tres paradigmas en cuestión. 3.1. El mal surge con el ser humano y sólo él es culpable de su existencia. 3.2. Dios o no existe o, de existir, debe necesariamente ser (sólo) bueno. 3.3. Todos nacemos libres e iguales; el mal es necesario para la libertad humana y por tanto para su dignidad. 
4. ¿Qué hacer con el mal? Frente a la justificación, la lucha relacional-integral. 4.1. Al mal se le puede y se le debe justificar o sólo cabe resignarse. 4.2. Frente al mal, sólo cabe oponer el bien o la integración de opuestos. 4.3. Frente al mal, llegado el caso, nos queda el misterio o la ciencia-razón. 5. En conclusión: ¿hacia un nuevo paradigma?

FECHA DE RECEPCIÓN: 22 DE 12 DE 2010 FECHA DE ACEPTACIÓN: 13 DE 05 DE 2011

\section{CÓMO SUPERAR UN DISCURSO SOBRE EL MAL OBSOLETO E INEFICAZ: EL ENFOQUE RELACIONAL-INTEGRAL}

«Si hay un problema que parece insoluble para la filosofía, para la ética y para la teología occidentales, es el problema del mal. Esquivarlo es la más fidedigna señal de banalidad de pensamiento y vida». ${ }^{1}$ El mal es un asunto difícil del que muchos prefieren ni oír, ni hablar o despacharlo con palabras simplificadoras, tal vez porque saben que está en juego todo lo que creemos saber sobre el ser humano y la realidad que nos rodea. De hecho, de la idea del mal que cada uno tenga depende el concepto de sí mismo, de su dignidad y de su aspiración a la felicidad, objetivo del que nadie reniega en principio. Este artículo trata de sacar al mal del bloqueo intelectual en el que lo mantienen el miedo, la pereza y la ignorancia. Lo que vamos a narrar no es probablemente la Verdad, no al menos toda la Verdad, pero si una interpretación plausible que puede llevar algo de luz a un asunto que se suele situar cerca de lo oscuro. Para ello intentaremos relacionar la escandalosa persistencia del mal en el mundo y un saber humano inherentemente limitado (y en permanente estado de construcción) incapaz de responder a preguntas, en apariencia tan sencillas, como: ¿por qué hay algo en lugar de nada? ¿o por qué existe este algo defectuoso que incluye al mal en lugar de otro algo que se compusiera sólo del bien?

¿Qué puede hacer el ser humano del siglo XXI para luchar contra el mal que no haya podido hacer en otras épocas? Que el mal sigue siendo algo pendiente de resolver se demuestra en los continuos intentos doctrinales de dar con nuevas respuestas a este problema antiguo. ${ }^{2}$ Como sostenía Francis Bacon hay algo de insano en el intento de hacer nuevas cosas sin utilizar al mismo tiempo nuevos medios. ${ }^{3}$ No obstante, cabe entender que el progreso consiste no tanto en destruir el equipaje (intelectual, cultural o social) con el que llegamos, sino en reinterpretarlo y reciclarlo a la luz de los nuevos descubrimientos y realidades para darle nuevas utilidades con objeto de seguir

\footnotetext{
${ }^{1}$ E. Trías, Diccionario del espíritu, Planeta, Barcelona, p. 109.

${ }^{2}$ En nuestro país, ver por ejemplo: A. Gil Ibáñez, Mal, religión y saber: una lucha relacional-integral frente a una realidad ambivalente, Universidad Complutense, Madrid, 2011(http://eprints.ucm.es/11963/); Instituto Universitario de Ciencias de las Religiones, Los rostros del mal: las manifestaciones del mal en las religiones, Khaf, Madrid, 2010; A. Torres Queiruga, Repensar el mal: de la ponerología a la teodicea, Trotta, Madrid, 2011.

${ }^{3}$ F. Bacon, The New Organon (editado por L. Jardine y M. Silverthorne), Cambridge University Press, Cambridge, 2000, p. 34, aforismo VI.
} 
avanzando más rápidos y seguros. Por ello planteamos un enfoque interdisciplinar (enfoque muy en boga, pero que muy pocos se atreven a llevar a la práctica) que busca el saber allí donde reside (aunque sea de forma ocasional) y no sólo en un lugar concreto. Nadie duda de que la especialización resulta imprescindible debido a la vasta extensión del conocimiento y a las limitadas capacidades del individuo. Sin embargo al mismo tiempo crecientemente se demuestra la incapacidad de una sola disciplina para dar respuestas globales y omnicomprensivas a problemas complejos. ${ }^{4}$ Una nueva respuesta tiene que tener en cuenta por tanto los nuevos descubrimientos científicos y el conocimiento de la mente, poniéndolo en relación con el saber filosófico y religioso, y sazonada esta receta culinaria con el saber presente en grandes obras literarias. ${ }^{5}$ Todo ello en un lenguaje accesible (para evitar la confusión en la que se esconde el mal) y articulado con un enfoque relacional-integral que no se limita a relacionar sino que pretende profundizar para llegar a integrar ópticas aparentemente diversas.

Existen dos obstáculos añadidos para profundizar en el problema-enigma del mal: los pre-juicios cognitivos y un cierto dogmatismo sectario. En efecto, son escasos los estudios sobre el origen del mal que afronten la cuestión sin ideas ni creencias preconcebidas, tratando meramente de ver «qué pasa aquí». La mayor parte de los enfoques adolecen de algún pre-juicio cognitivo que contamina el debate, bien en torno a un determinado concepto de la dignidad/autonomía «natural» del ser humano, o bien en relación con un Dios que necesariamente debe ser uno, bueno y omnipotente. ¿Pensamos lo que pensamos como consecuencia de un proceso de reflexión fundamentalmente objetivo o es lo que necesitamos pensar para mantener un determinado concepto de ser humano? A ello se añade un habitual enfoque dogmático anti-religioso (todo lo que dice la religión debe ser falso) o pro-religión (todo lo que dice la religión debe ser verdadero). Por contra, el objetivo de este artículo es que sus propuestas valgan tanto para creyentes como para no creyentes, pues una de las estrategias que sirven al mantenimiento del mal es la división y el conflicto. A fin de cuentas «quienes se profesan creyentes y los que dicen no creer se enfrentan a la misma pregunta: ¿tendré la fuerza y la dignidad humana suficiente para afrontar lo malo que me espera en la vida? Las respuestas de los unos y los otros sí parecen resultar muy dispares: tras la experiencia bautismal o infernal del dolor, algunos se vuelven creyentes y otros agnósticos o ateos». ${ }^{6}$

Algún firme defensor del paradigma racional podría sorprenderle que nos centremos en la religión en un momento en que lo más común es darla por finiquitada. Pero reducir todo el saber religioso a mera superstición es un claro exceso pues la religión incluye el intento honesto (y a veces desesperado) de relacionarse directamente con lo invisible a nuestros sentidos, con lo desconocido, con lo absolutamente otro,

\footnotetext{
${ }^{4}$ E. Morin, Introducción al pensamiento complejo (trad. M. Pakman), Gedisa, Barcelona, 1995, pp. 21, 22.

5 Ya F. Bacon hablaba de tres filosofías: la divina, la natural y la humana [El avance del saber (trad. $M^{\mathrm{a}}$.L. Balseiro), Alianza, Madrid, 1988, pp. 100ss]. Recientemente, por ejemplo, Antonio R. Damasio, con objeto de enfrentarse al funcionamiento de la mente, ha puesto en relación la neurología, la biología y la filosofía (Self Comes to Mind: Constructing the Conscious Mind, William Heinemann, Londres, 2010).

${ }^{6}$ J. Trebolle, Libro de los salmos. Religión, poder y saber, Trotta, Madrid, 2001, p. 31.
} 
con el misterio que permanentemente se nos escapa; lo «sobrenatural» como sinónimo de «religioso» que proponía Emile Durkheim: «todo orden de cosas que vaya más allá del alcance de nuestro entendimiento (...) el mundo del misterio, de lo incognoscible, de lo incomprensible». ${ }^{7}$ Un campo que sigue abierto mientras la ciencia-razón por sí sola no sea capaz de responder a todas nuestras preguntas y garantizar nuestra felicidad pues lo irracional o a-racional no es necesariamente sinónimo de irreal. Al fin y al cabo la aparición del Homo religiosus va unida a la formación del córtex prefrontal, precisamente cuando los humanos adquirieron la capacidad de autorreflexión, y ha servido eficazmente a nuestra supervivencia biológica hasta la fecha. ${ }^{8}$

La religión, por otra parte, sigue siendo al día de hoy la que de manera más constante, y a veces agónica se ha enfrentado al problema del mal. Además los textos religiosos y los mitos (se crea en Dios o no) representan no sólo la psicología y la sabiduría de un pueblo legitimadas por el tiempo, sino un símbolo que incita a la reflexión, uniendo de esta manera revelación y razón («el mito da que pensar»), ${ }^{9}$ así como un reflejo/expresión de un camino de iniciación (psicológico) para acabar de completarse como ser humano o subir de nivel en la escala de conciencia, eso a lo que en términos religiosos se denomina «salvarse». Por otra parte, el texto religioso no es necesariamente algo cerrado y fijo sino que puede ser objeto de comentario y crítica, tanto desde el punto de vista de su coherencia interna, de su comparación con lo que otros textos religiosos proponen (intertextualidad), como desde lo que sugieren sobre iguales o parecidos asuntos otras disciplinas en principio no religiosas (interdisciplinariedad) en su posible aplicación al mundo de hoy en día.

En definitiva, vivimos bajo presupuestos (parcialmente) fallidos que se resisten a sucumbir. Como consecuencia para un nuevo discurso sobre el mal se deben poner en cuestión algunos de los paradigmas que dominan el discurso social sobre el mal y que aparecen en la base de lo política, pero también filosófica o religiosamente correcto (que hemos concretado en diez), contraponiendo diez tesis alternativas (o contra-paradigmas) cada una acompañada de su correspondiente justificación.

\section{CONCEPTO Y EXISTENCIA DEL MAL: CUATRO PARADIGMAS EN CUESTIÓN}

\subsection{HAY QUE EXCLUIR AL MAL DEL DISCURSO SOCIAL POR INCOMPRENSIBLE}

Frente a ello, sostenemos como alternativa que «negar o ignorar la realidad del mal constituye un exceso paralizador, como lo es sostener que todo es malo o atribuir (sin más matices) este mal a un sujeto con cola y cuernos». Desde antiguo hasta tiem-

${ }^{7}$ E. Durkheim, Las formas elementales de la vida religiosa: el sistema totémico en Australia (trad. R. Ramos), Akal, Madrid, 1982, p. 22.

${ }^{8}$ M. Blume, «Homo religiosus», Mente y Cerebro, $\mathrm{n}^{\circ} 45$ (2010), pp. 40-49.

${ }^{9}$ P. Ricoeur, Le conflit des interprétations: essais d’herméneutique, du Seuil, Paris, 1969, p. 16. 
pos recientes una de las técnicas más recurrentes para lidiar contra el mal ha consistido en ignorarlo, ocultarlo (oscuridad), apartarse de él, o sustituirlo y compensarlo con todo aquello que nos acercara al bien (la luz), a lo considerado en cada época como positivo. De la estrategia huidiza tenemos un primer ejemplo en el consejo que da Circe a Ulises en su vuelta a Ítaca: huir de Escila y Caribdis y no enfrentarse a ellas pues el mal que ambas representan resulta insuperable para el ser humano. Ignorar el mal («vivir como si no existiera») para muchos sería la mejor manera de hacerle perder su poder sobre el ser humano y de superar el temor que inspira. Esta propuesta tiene sin duda su importancia pues representa lo que ha venido haciendo el mundo occidental de forma recurrente -en particular a partir de la Ilustración-no sólo en círculos paganos sino en los propios ambientes religiosos.

La estrategia sustitutiva podría quedar resumida en el adagio de: «allí donde veas mal pon tú el bien». Esta estrategia, sin embargo, aunque puede mostrar eficacia a corto y medio plazo, tarde o temprano no evita (al menos por sí sola) que el mal resurja o se manifieste de algún modo por encima de esa voluntariosa actitud, por ejemplo a través de algún acontecimiento doloroso tanto a nivel individual (muerte de un hijo a manos de unos indeseables, por ejemplo) o colectivo. ${ }^{10}$ Ello es muestra de que al mal se le había apartado pero en realidad no había sido vencido.

No parece por tanto que ninguno de estos enfoques haya sido coronado con el éxito. De hecho, hoy la agenda del mundo sigue marcada por hechos que contienen al mal: guerras, terrorismo, hambre, catástrofes, epidemia, gran contaminación... Incluso se ha anunciado que «(...) el dolor jamás dejará de ocupar el primer puesto en la mala conciencia universal». ${ }^{11}$ Como consecuencia de ese fracaso - tanto de la razón, ya sea en forma de ideología o como ciencia, como de la religión-, pero también por la necesidad psicológica de afirmar el dominio del ser humano sobre sí mismo y sobre su entorno, se consolida una huída o enmascaramiento de la realidad del mal, principalmente en occidente.

De hecho, aunque pueda sorprender, hay más de un paralelismo en la forma en que la religión y el racionalismo se han enfrentado al problema del mal. En ambos cabe observar una primera fase de optimismo donde se espera (ingenuamente) que Dios, restableciendo la alianza con el ser humano, o el progreso humano extendido de forma planetaria (primero la revolución francesa, luego la revolución industrial, más tarde la revolución comunista donde una vez resuelta la lucha de clases se acabaría el problema, y últimamente la revolución tecnológica y científica) terminarían con el mal en el mundo; pero nada más lejos de la realidad. Una segunda fase de cierta frustración, en la que se concentra la razón de todos los males en un sujeto identificable pero alejado de la mayoría (Satán-diablo versus Hitler, gran capital, psicópata, o dictadorgenocida). Una tercera fase de rendición donde las dos doctrinas coinciden en asu-

\footnotetext{
10 Vid. W. James. Las variedades de la experiencia religiosa (trad. J.F. Yvars), Península, Barcelona, 1999 (3. ${ }^{\mathrm{a}}$ ed.), p. 129.

${ }^{11}$ R. Sánchez Ferlosio, Mientras no cambien los dioses, nada ha cambiado, Alianza, Madrid, 1987 (2ª reimp, $1^{\mathrm{a}}$ ed, 1986), p. 90 .
} 
mir que el ser humano es el único culpable (libertad de la criatura versus el mal moral, único existente). Una cuarta fase que aplaza sine die la solución del problema, bien a una vida supuestamente maravillosa post mortem (la civitas Dei de S. Agustín), bien a una época dorada por venir (civitas terrena ideal) donde triunfará definitivamente el progreso (científico). Para acabar con una última fase que derivaría en puro escapismo al defender pura y simplemente la inexistencia del mal: el privatio boni agustiniano versus el relativismo moral (todo es cuestión de gustos y opiniones).

En resumen, en una conclusión común a ciencia, filosofía y religión sería: lo que no se comprende o molesta para el paradigma dominante se convierte bien en irrelevante, en no existente, o se esconde bajo una etiqueta tranquilizadora pues lo que está clasificado (aunque sea como enfermedad mental) parece que ya se controla. Pero de verdad ¿se puede ser creyente sin creer en el mal-diablo?, ¿se puede ser racional sin mirar al dolor de las víctimas inocentes o desvalidas?

\subsection{EL MAL NO TIENE EXISTENCIA PROPIA, ES UNA MERA AUSENCIA DEL BIEN O ALGO IRRELEVANTE}

Por el contrario sostenemos que «el mal existe: es un algo-alguien que goza de presencia y existencia propias». La literatura apocalíptica pospone la felicidad a un hipotético más allá, dando de antemano por perdido el más acá y planteando así la irrelevancia sustantiva del mal terreno. S. Agustín complementa esta estrategia religiosa con la definición del mal como privatio boni pues «(...) todas las cosas que no han sido hechas buenas, no existen... El Mal no es, por lo tanto, nada porque no ha sido hecho». ${ }^{12}$ Pero no es tan claro que «el ser» sea el bien, y el mal su ausencia. Si el bien abarcara todo lo existente, su alternativa sería la nada inerte más absoluta, vacía de cualquier contenido, y no un mal que funciona como sustrato preexistente. Es más, en no raras ocasiones la realidad de las tragedias o del dolor muestra una más vigorosa y agresiva «presencia» que la del bien ya que se manifiesta en fenómenos claramente tangibles, observables en la realidad cotidiana, cuantificables en cifras preocupantes y con características aterradoras (muertes violentas, enfermedades, hambre, guerras, conflictos, locura, etc...). Por último, que el mal tiene existencia (al menos tanta como el bien) se demuestra por los efectos que produce (por de pronto el sufrimiento), del mismo modo que tanto la materia y energía oscuras como los agujeros negros no se pueden ver directamente (parecen no existir) y sólo pueden ser detectados por las consecuencias que provocan.

En todo caso, aunque se pretendiera considerar al mal como una categoría irrelevante o como un mero producto de la imaginación (o del imaginario colectivo) todavía debería explicarse por qué se manifiesta en nuestra imaginación de forma recurrente en culturas y tiempos diversos y por qué el ser humano a pesar de sus avances

${ }^{12}$ Agustín de Hipona, Soliloquios, en Obras completas, Biblioteca de Autores Cristianos, Madrid, 1978, cap. V, p. 324. 
en el terreno intelectual y de la tecnología se muestra recurrentemente incapaz de liberarse de esa «categoría» aparentemente tan superflua así como de las experiencias a ella conectadas. ${ }^{13}$ En este sentido, la presencia del mal en el mundo nos despierta de cualquier sueño de idealismo excesivo pues el ser humano no puede crear «voluntariamente» una realidad que incluya al mal.

\subsection{O «TODO ES BLANCO O NEGRO» (MANIQUEÍSMO-DUALISMO) O «TODO VALE LO MISMO» (RELATIVISMO-PANTEÍSMO)}

Frente a ello sostenemos que «la realidad es ambivalente ('una cosa es tanto lo que es como lo que no es') pero ello no implica que no exista ni que todo valga lo mismo». El carácter ambivalente no se circunscribe a nuestra época pues ya sugeriría Parménides de Elea hace 2.400 años que una cosa puede ser verdad y mentira al mismo tiempo. Los textos religiosos contemplan asimismo algunos contenidos ambivalentes del mal: la esperanza-espera, considerada al mismo tiempo el último de los males de la caja de Pandora en cuanto antídoto de la acción («quien espera, desespera») y el principal recurso contra el mal; la función de la procreación y el deseo (fuente de vida y de pecado); o el propio papel de la muerte, mal o bien según el concepto y significado (a su vez ambivalente) que se maneje de la propia muerte y de la vida.

No obstante, en nuestro tiempo el carácter ambivalente se ha reforzado. El propio Zigmunt Bauman considera a la ambivalencia, desde el campo de la sociología, como una característica de la modernidad y la post-modernidad. ${ }^{14}$ Basta acudir a los últimos descubrimientos en la física cuántica que nos presentan a la realidad como algo que existe y no existe al tiempo en términos de probabilidad (gato de Schrödinger) y donde «lo mismo» puede comportarse alternativamente como partícula y como onda. Hasta se habla de un mundo con un número no definido de dimensiones, de multimundos, mundos paralelos o que bajo una realidad «explicada» existe un orden implicado. ${ }^{15}$ Desde el campo de la psicología, Freud alertó asimismo del carácter ambivalente de la mente humana que se demostraría por ejemplo en el conflicto edípico o en la relación prototípica entre el padre y sus hijos, quienes a la vez lo aman y lo odian, le quieren y lo temen. ${ }^{16}$ Del mismo modo, C.G. Jung hablaba de la coincidencia oppositorum (unión de opuestos) o de la idea paradójica que encierra la coniunctio al enlazar pares de «opuestos [que] se contraponen de manera hostil o se atraen mutua y amorosamente» (p. ej. hombre y mujer). ${ }^{17}$

\footnotetext{
${ }^{13}$ B. Meyer, «Le Diable», Terrain. Revue d'ethnologie de l'Europe no 50 (2008), pp. 4-13, 12 y13.

${ }^{14}$ Vid. Z. Bauman, Modernidad y ambivalencia (trad. E. y M. Aguiluz Ibargüen), Anthropos, Barcelona, 2005.

${ }^{15}$ D. Bohm, Wholeness and the Implicate Order, Routlege and Kegan Paul, London, 1981.

${ }^{16}$ Cfr. R.J. Bernstein, El mal radical: una indagación filosófica (trad. Marcelo G. Burello), ed. Lilmond, Buenos Aires, 2004, pp. 191ss.

${ }^{17}$ C.G. Jung, Mysterium coniunctionis (con la colaboración de M-L von Franz), (trad. J. Rivera y J. Navarro), Obra completa, vol. 14, Trotta, Madrid, 2002, p. 441.
} 
Aceptar la ambivalencia de la realidad no implica negar su existencia (otra cosa es que ésta sea como pensamos que es), como aceptar determinados contenidos ambivalentes del mal no significa negar que éste goce de una presencia que debe ser combatida. El mal-exceso marca el límite a la ambivalencia, el punto donde ésta no puede funcionar como excusa pues el sufrimiento nos despierta de sueños interesados de irrealidad. Por ejemplo, potencialmente cabría discutir en términos «intelectuales» (aunque nos resulte difícil de aceptar a los occidentales) que el incesto sea en sí mismo algo estrictamente malo pues (como demostrara Freud) no siempre ni en toda cultura así ha sido considerado, pero cuando un padre encierra a su hija en un sótano durante veinticinco años, la viola repetidamente, tiene varios hijos con ella que a su vez conviven encerrados, nadie en su sano juicio puede defender que no haya en ese hecho algo oscuro y perverso esencial, mucho más cuando ese padre («Monstruo de Amsteten») mantenía una vida «normal» con el resto de la gente, es decir cuando ni siquiera puede argumentarse que fuera presa de una locura (momentánea). Contra el relativismo radical cabe afirmar que: «no todo vale, ni todo vale lo mismo» aunque de forma ambivalente podamos aceptar que toda gran verdad es la contraposición de otra gran verdad.

\subsection{EL MAL NO PUEDE SER IDENTIFICADO NI DEFINIDO}

Nosotros por el contrario sostenemos que «es posible encontrar algunos elementos que caracterizan y definen al mal».

\section{a) ¿Qué es el mal?}

Se han producido varios intentos de definir el mal a lo largo de la historia. Así, desde la filosofía, Spinoza identificó lo malo con lo que sabemos con certeza que impide que poseamos algún bien, mientras éste sería lo que sabemos con certeza que nos es útil. ${ }^{18}$ Este tipo de definiciones, sin embargo, no explican mucho porque remiten a cuestionarnos qué cabe entender a su vez por útil o por bien. Por su parte, desde un punto de vista psicológico, Stefan Zweig ha definido lo demoníaco como «esa inquietud innata, y esencial a todo hombre, que lo separa de sí mismo y lo arrastra hacia lo infinito, hacia lo elemental. Es como si la Naturaleza hubiese dejado una pequeña porción de aquel caos primitivo dentro de cada alma y esa parte quisiera apasionadamente volver al elemento de donde salió: a lo ultrahumano, a lo abstracto». ${ }^{19}$

En los tiempos modernos son mayoría los pensadores, tanto religiosos como ateos o agnósticos, que aducen numerosas excusas para acometer con éxito esta tarea definitoria, aludiendo por ejemplo a las múltiples vertientes y contenidos del mal, todos los cuales plantean a su vez diversos problemas conceptuales: sufrimiento, violencia,

\footnotetext{
${ }^{18}$ B. Spinoza, Ética demostrada según el orden geométrico (trad. e introd. V. Peña García, notas y epílogo G. Albiac), Tecnos, Madrid, 2007, IV, p. 290.

19 S. Zweig, La lucha contra el demonio (Hölderlin, Kleist, Nietzsche), (trad. J. Verdaguer), Acantilado, Barcelona, 1999, p. 11.
} 
pereza (indolencia), muerte, miedo (cobardía), ignorancia (engaño), confusión, «lo otro», lo siniestro, lo perverso... No obstante, aquí defendemos que todas esas facetas pueden quedar comprendidas en los siguientes elementos que caracterizarían así a la esencia del mal: un acaecer con presencia y contenido propios (un «algo-alguien», fuerza, energía, pensamiento), caracterizado por lo excesivo o extremo (el mal devastador que rompe el equilibrio o la armonía), el sufrimiento (potencialmente desmesurado), lo falso o engañoso (que rompe la verdad o el conocimiento cierto) y la intención cruel o perversa (o el «ensañamiento» que quita el carácter humano a quien la practica como quien experimenta placer ante el dolor ajeno). Un mal por tanto que actúa a través del conflicto (violencia), la división (debilitamiento), la confusión (ignorancia) y el engaño como falso saber que, por ejemplo, identifica al mal erróneamente con «el otro» para justificar guerras étnicas o exterminios (Holocausto). ${ }^{20}$

\section{b) El mal como exceso: mal moral-mal objetivo-mal natural}

De todos los elementos propuestos, destaca el «exceso» (cuantitativo pero sobre todo cualitativo) como característica fundamental. A menudo se cita la inscripción que figuraba en el frontispicio del Oráculo de Delfos - «conócete a ti mismo y conocerás a los dioses»-, pero resulta más infrecuente que se destaque la segunda inscripción -«nada en exceso»-, no menos importante. En efecto, ¿Qué tienen en común acontecimientos como los terremotos devastadores de Lisboa o el más reciente de Haití, los tsunamis, y personajes como Hitler o el «monstruo de Amsteten», el asesino en serie, el psicópata social? Pues su carácter excesivo, el cual potencialmente se da incluso en el amor y el deseo, degenerando así en lo posesivo o lo perverso.

La intención de hacer daño a otro (cruel o perversa) determina el mal moral, pero existe también un mal incondicional u objetivo que no requiere motivos para actuar, prototipo de mal perverso, de mal amoral (o mal «molar» como prototipo de dolor excesivo e inútil) y que aparecería encarnado «literariamente», por ejemplo, por el Yago de Otelo. ${ }^{21}$ Este exceso se relaciona asimismo con la «protervia» o perversa obstinación y perseverancia en el mal..$^{22} \mathrm{Y}$ es que si hay una enseñanza de la historia del saber es que conviene huir de lo/s extremo/s porque lo excesivo abre la puerta al mal y acaba por destruir la apuesta que podría en un principio parecer válida, provocando una reacción (como atestigua la física) semejante pero de sentido inverso. ${ }^{23}$ En este sentido, la contraposición bien-mal no sería una más (como las de caliente-frío o día-noche)

${ }^{20}$ El engaño también se ramificaría en el deleite en engañar (impostura) y la propensión a ser engañado (credulidad), dos caras en realidad de la misma moneda: cfr. F. Bacon, El avance del saber, op. cit, p. 43.

${ }^{21}$ R. Raatzsch, The Apologetics of Evil: The Case of Iago (trad. L. Löb), Princeton University Press, Princeton y Oxford, 2009, pp. 14, 20, 49, 99.

${ }^{22}$ M. Fernández del Riesgo Antropología de la muerte: los límites de la razón y el exceso de la religión, Síntesis, Madrid, 2007, p. 149.

${ }^{23}$ Así pasó con el fracaso del liberalismo (fin del S. XIX-principios de S. XX) debido a sus excesos cuando se permitió trabajar a niños y mujeres en trabajos agotadores, sin horarios, sin ninguna protección social, y así pasó con el fracaso de su reacción dialéctica, el comunismo, convertido a su vez en una dictadura de burócratas ineficaces que acabó por dejar vacías las arcas del erario público, provocando de esta manera la vuelta a un nuevo liberalismo «ideológicamente» reforzado. 
sino la oposición por excelencia, singular y ambivalente, que da valor a todas las demás (lo caliente y lo frío puede ser a su vez malo o bueno según sea excesivo o no).

Por último, superando nuestros pre-juicios antropológicos (el ser humano «debe ser» la medida de todas las cosas) cabe hablar también de un mal natural o cósmico. La ciencia usa el adjetivo oscuro para referirse a una anomalía o a lo desconocido: hay agujeros negros, materia y energía oscura y materia genómica oscura. Pero también existen enanas blancas vampiros, agujeros negros supermasivos, supernovas y estrellas de neutrones que producen violentas explosiones (inútiles) de rayos gamma, etc... De hecho, algunos agujeros negros, llamados «asesinos», son capaces de destruir galaxias enteras, no devorándolas como resultaría de su condición de absorbedores de materia, sino bombardeándolas con energía letal. En el universo se observan excesos cósmicos que frustran el desarrollo armónico y que pueden producir directa o indirectamente sufrimiento aunque sea en un animal no humano: por ejemplo la desaparición de los dinosaurios por el choque (excesivo) de un meteorito, o cuando los animales comenzaron a devorarse unos a otros.

\section{ORIGEN Y CAUSAS DEL MAL: TRES PARADIGMAS EN CUESTIÓN}

\subsection{EL MAL SURGE CON EL SER HUMANO Y SÓLO ÉL ES CULPABLE DE SU EXISTENCIA}

Por el contrario, sostenemos que «el mal precede y acompaña al ser humano a pesar de sí mismo». Desde un punto de vista religioso sólo puede haber dos agentes causantes del mal: Dios -o algunos dioses y demonios- y el ser humano. Sin embargo, creyentes y ateos coinciden en intentar echar en exclusiva sobre los hombros del ser humano el pesado fardo de la culpa del mal, unos para liberar a Dios de toda responsabilidad -aunque éste no haya pedido ninguna ayuda para ello-y otros porque muerto Dios sólo cabe mirar al ser humano como potencial agente capaz de actuar por sí mismo. De hecho, en Occidente la muerte de Dios ha venido acompañada de un endiosamiento del ser humano, lo que en términos del mal significa que o bien se hace a éste culpable de todo, o, como alternativa, al mal se le ignora o se le esconde bajo la excusa del relativismo.

No obstante, todos los textos religiosos podrían comenzar con una frase del tipo: «Al principio era el mal...». Es decir, un mal primigenio que precede y se impone claramente al ser humano e incluso en ocasiones a los propios dioses. Este mal originario se presenta (según los textos) como caos (el origen de todo en el mundo griego de Hesiodo), excesos variados, conflicto familiar entre dioses, aguas primordiales devoradoras, monstruos primigenios, dragones y serpientes. La misma conclusión cabe detraer de la literatura apocalíptica y de la mística (severidad, inarmonía y noche oscura), así como de la presencia, desde el principio de los tiempos hasta nuestros días, de una figura personificada del mal: espíritu de la falsedad o del mal, larga lista de dioses oscuros y demonios en prácticamente todas las culturas. 
En el mismo Génesis (1: 1-4) se dice: «En el principio creó Dios los cielos y la tierra. La tierra era caos y confusión y oscuridad por encima del abismo, y un viento de Dios aleteaba por encima de las aguas. Dijo Dios: 'Haya luz', y hubo luz. Vio Dios que la luz estaba bien, y apartó Dios la luz de la oscuridad». ${ }^{24} \mathrm{Y}$ en el maniqueísmo (dualismo) se señala: «Antes de la existencia del cielo y la tierra y de todo lo que hay en ellos hubo dos naturalezas, una buena y otra mala». ${ }^{25}$ Dos naturalezas separadas, que permanecieron como tales hasta que la Oscuridad alcanzó sus límites exteriores y entró en contacto con la Luz: «La Oscuridad estaba dividida contra sí misma: el árbol contra sus frutos y los frutos contra el árbol. La lucha y la amargura pertenecen a la naturaleza de sus partes; la dulce quietud es desconocida para ella...». Pero cuando se encuentra por primera vez con la Luz: «las fuerzas atacaron en un solo cuerpo, como si no conocieran a su adversario, porque nunca habían sabido de la Deidad» (H. Jonas, op.cit., p. 235). ${ }^{26}$

Por su parte, hoy la ciencia nos dice que el $95 \%$ de lo que existe está compuesto por energía y materia oscura (¿la religión se adelantó a la ciencia?) y la psicología señala que la mayor parte de nuestra mente es inconsciente (¿una reminiscencia del caos primordial todavía no superado del todo?). Desde el punto de vista de la ciencia-biología puede decirse asimismo que el mal-sufrimiento hace su aparición con los animales depredadores que rompen el equilibrio paritario existente entre plantas e insectos. Sólo desde un enfoque radicalmente antropocéntrico-victimista pueden ignorarse estos datos, o desde quien considera el sufrimiento de los animales como irrelevante. Hay igualmente mecanismos que contribuyen al origen del mal y que se presentan como elementos inherentes a la realidad o a su funcionamiento pues surgen y se mantienen reiteradamente al margen la propia voluntad de los individuos que los

${ }^{24}$ (la cursiva es nuestra). En el Génesis el mal primigenio se manifiesta además en la existencia de la serpiente tentadora, en la propia prohibición divina y en un sistema penal divino que no pasaría los estándares modernos aplicables a los códigos penales fijados desde el Marqués de Beccaría (C. Beccaria, Tratado de los delitos y las penas, edición facsimil a cargo del Ministerio de Justicia y la Biblioteca Nacional, Madrid, 1993) que entre otras cosas determina que la pena debe ser proporcional al delito. Nuestra condena parece ser sin remedio y sin atenuantes, haya o no haya individuos justos y arrepentimiento, lo que se confirmará a partir de Noé y el diluvio universal, con la contrapartida de que Dios garantizará la continuidad de la especie humana, también con independencia de su comportamiento. Esto se refleja en la protección de la progenie de Caín a pesar de ser el primer asesino (y al mismo tiempo padre) de la humanidad.

25 Palabras de Mani citadas por H. Jonas, La religión gnóstica. El mensaje del Dios Extraño y los comienzos del cristianismo (trad. M. Gutiérrez), Siruela, Madrid, 2003 (2 ed.), p. 232.

${ }^{26}$ En la Comunidad de Qumrán se dice que un Dios de sabiduría creó todo lo que es y será, y dos espíritus: el de la verdad y el de la falsedad, sobre los que el hombre caminará hasta la venida del creador. En el Libro de Enoc el mal entra en la tierra por la influencia de fuerzas sobrenaturales que se «dejan seducir» por las hijas de los hombres, y que transfieren conocimientos a los humanos con los que éstos empiezan a guerrear. Marduk (Enuma Elish) vence a Tiamat con terribles armas lo mismo que Baal (mitos cananeos) sobre Yam o los enfrentamientos no menos crueles que se suceden entre Urano, Cronos y Zeus, dentro de la mitología griega. Y las razones que tienen los dioses para crearnos tampoco parecen siempre del todo desinteresadas pues en ocasiones somos meros encargados de hacer los trabajos que a ellos les molestan. Del mismo modo, en numerosos textos religiosos aparecen las secuelas de una lucha primigenia, con el común denominador de que el supuesto vencedor encarnaría al bien. Esto ocurre de forma muy sintomática en el caso del enfrentamiento entre Marduk y Tiamat. Ésta antes de ser molestada por unos dioses más jóvenes y ruidosos no era sino una venerable anciana, y aquél no parece ser menos violento ni utilizar armas y estrategias menos terribles que ésta, pero a partir de su victoria pasa a arrogarse la representación de las fuerzas del bien. 
sufren, reflejando en definitiva que la lucha y la violencia forman parte de la vida: la violencia mimética (la víctima expiatoria, propiciatoria o sustitutiva), la división y el conflicto, y una evolución biológica que expulsa al más débil.

Es más, frente a la presunción que atribuye a la aparición del ser humano el mal en el mundo, cabe sostener que es gracias a nuestros antepasados que el mal se socializa y las enfermedades (mentales) se resuelven, estableciéndose mecanismos de control y corrección (códigos, policía, jueces, médicos, psicólogos). Es decir, es el bien (y su compañera la compasión o la preocupación por los débiles o las víctimas) el que aparece en términos evolutivos unido a existencia del ser humano contra el principio «biológicamente despiadado» de la ley del más fuerte, donde el menos adaptado era simplemente eliminado sin miramientos, todo ello en beneficio del único fin relevante: la perpetuación de la vida cueste lo que cueste. No obstante, una vez más, de forma ambivalente, es justo reconocer que con el ser humano se instauran igualmente nuevas formas de maldad antes desconocidas, unidas por ejemplo a la búsqueda de placer a todo precio, o a asegurar la vanidad y preeminencia de los unos sobre otros. Parece como si la evolución de las especies a medida que produce seres más avanzados, en cuanto a su inteligencia o habilidades artístico-creativas, tuviera que pagar el peaje del incremento de su capacidad para ejercer la maldad en todas sus posibles fórmulas.

\subsection{DIOS O NO EXISTE O, DE EXISTIR, DEBE NECESARIAMENTE SER (SÓLO) BUENO}

Por el contrario sostenemos que «todos vivimos con un concepto de Dios (o de lo divino) a cuestas, el problema es qué concepto manejamos; sólo puede ser defendida (racionalmente) la existencia de un solo Dios si éste incluye también al mal».

\section{a) ¿Un qué o un quién?}

La idea de Dios le ha sido históricamente útil al ser humano para intentar comprender el mundo y explicar cómo hemos surgido en este rincón ignoto del universo; la pregunta es si sigue siéndolo hoy. La ciencia, contra lo que se pudiera pensar (incluidos los ateos más recalcitrantes) no elimina a Dios sino sustituye la idea de un agente personal (un quién) por un qué: leyes naturales y mecanismos (evolución) que comparten características con lo divino (auto-creadas o sin causa y origen conocidos, de duración eterna, etc...). Llegado el caso uno debe optar entre creer en una inteligencia causante o en el azar, es decir o se cree en algún concepto de Dios-dioses-similar o se cree en las casualidades; cuál de esas opciones sea más terrible e irracional para el ser humano está por ver. Además, «cuando se deja de creer en Dios, no queda más remedio que creer en los hombres. Y entonces quizá se haga el sorprendente descubrimiento de que era más fácil creer en el hombre cuando se hacía un rodeo a través de Dios». ${ }^{27}$

${ }^{27}$ R. Safranski, El mal o el drama de la libertad (trad. R. Gabás), Tusquets, Barcelona, 2002 (2a ed.), p 246. 
El ser humano a pesar de haber intentado en varias ocasiones (y seguir intentándolo) matar a Dios no se ha liberado de la necesidad de absolutos como demuestran filósofos de la sospecha como Hegel (la Historia), Marx (el materialismo histórico) y Nietzsche (la nada y el eterno retorno). Tampoco la ciencia se libra fácilmente del concepto de «infinito», aunque lo intente en ocasiones desesperadamente, ya que de aceptar una serie infinita de elementos la prueba matemática de cualquier cálculo se vería seriamente limitada en términos de veracidad y coherencia. Ante ello un formalista estricto ignorará el problema y seguirá trabajando, pero no es de extrañar que la mayoría de los científicos que niegan la realidad espiritual defiendan paralelamente el universo «debe» ser espacialmente finito, aunque potencialmente ilimitado, y con un origen temporal concreto pero difuso (el tiempo no existiría «antes» del Big Bang) aunque potencialmente cíclico y por tanto eterno.

En el campo de la literatura, Isaac B. Singer, en su relato «Algo existe» pone en boca de un rabino que trata de renunciar a su religión la siguiente afirmación: «Todo el mundo adora a algún ídolo -musitó el rabino-. Inventan dioses y les sirven». ${ }^{28}$ Es decir que los que renuncian a la religión tiende a imitar lo peor de ésta. Y sin embargo... cabe plantear que, más allá de posiciones terminológicas (las grandes discusiones suelen deberse a que se otorga diverso significado a las mismas palabras), todos aceptamos que vivimos dentro de una realidad misteriosa y ambivalente basada en un sistema ordenado y complejo que se comporta de forma inteligente (llámesele Dios o no). La única alternativa real (y ambivalente) es si eso-ese es al mismo tiempo la nada (cfr. mística y religiones orientales).

\section{b) El lado oscuro de la realidad y de los dioses}

¿Es buena la vida? ¿Lo es necesariamente Dios o lo que esta idea representa? ¿Realmente «vio Dios que cuanto había hecho era bueno» (Gen. 1: 31)? Existe la presunción de que hay una tendencia automática del mundo (el progreso o la bondad innata de Dios) que empuja hacia una mejora permanente, pero lo cierto es que no existe evolución psicológica del individuo (sus conflictos son los mismos desde hace milenios) y que la realidad tiende al caos y a la dialéctica (automática) construccióndestrucción, lo que sólo se impide manteniendo un esfuerzo constante en contra. ${ }^{29} \mathrm{De}$ hecho, tanto la tradición judía como la cristiana prevén que la anunciada llegada del mesías (por primera o segunda vez) se verá acompañada de grandes sufrimientos y desgracias, lo que esconde un cierto fatalismo que la historia no hace sino corroborar.

¿Por qué entonces la creencias en una esencia «buena» de la vida? El ser humano como animal sujeto a la ley de la evolución tendería a eliminar todo aquel conocimiento (real o potencial) que pusiera en peligro su propia supervivencia o la de la es-

\footnotetext{
${ }^{28}$ I. B. Singer, Un amigo de Kafka y otros relatos (ed. y trad. P. Alonso), Cátedra, Madrid, 1990, pp. 269299, p. 298.

${ }^{29}$ En efecto, todos los conflictos de los mitos antiguos subsisten en la actualidad: el generacional entre padres-hijos (Génesis, Hesíodo) o abuelos-nietos ruidosos y ambiciosos (Tiamat), el de género entre hombre-mujer (Génesis, Hesíodo, violación de las mujeres por los vigilantes en Enoc), el fraternal entre hermanos (Baal, Hesíodo, Caín-Abel), el miedo a la autoridad y a lo desconocido (Génesis, Tiamat, Hesíodo), la falta de autoestima y sentimiento de ser injustamente tratado (Job) etc...
} 
pecie. En este sentido, el psicólogo social Melvin Lerner argumentó hace algunos años que, por una variada serie de razones, el ser humano está motivado para ver el mundo como un lugar justo y moral donde lo que le ocurre a la gente se relaciona con lo que se merecen. Cuando pedía a los participantes en sus experimentos que valoraran las buenas cosas que les ocurrían a personas poco virtuosas o malos sucesos a personas honestas y trabajadoras, trataban de buscar alguna justificación en la falsedad de su condición o en posibles compensaciones en un futuro en uno u otro sentido. ${ }^{30} \mathrm{Re}$ sulta curioso lo similar que suena todo esto con la primera parte del Libro de Job de la Biblia. Y sin embargo basten dos ejemplos: el suicidio se situó en 2008 como la primera causa externa de defunción en España, con 3.421 personas fallecidas, reemplazando así a los accidentes de tráfico, y tampoco resulta fácil la vida, por ejemplo, para las mujeres entre 15 y 25 años de las zonas rurales de China e India cuya primera causa de mortalidad es la maternidad y el suicidio. ${ }^{31}$

Otro pre-juicio valorativo paralelo en esta materia es considerar que Dios, de existir, debe ser necesariamente (sólo) bueno (al menos en el mundo monoteísta) pues si no resultaría demasiado terrible, insoportable o absurdo. Pero ¿por qué ese empeño en justificar a un Dios silente, a un Dios que calla? ¿No resulta una afrenta contra la propia omnipotencia divina? Cabe sostener de nuevo que las razones de esta obsesión responden más a una necesidad psicológica del individuo, que a una búsqueda sincera de la Verdad o una necesidad ontológica del propio Dios. Esta actitud pone en evidencia en todo caso al que la practica ya que su fe queda condicionada a que se demuestre que el Ser Supremo reúne determinadas características y no otras. De hecho, el que cree en Dios «a condición» de que sea sólo bueno se parece mucho al ateo que frente al mal llega a la conclusión de que no merece la pena creer en Dios. Incluso pretender por parte del creyente saber cómo es Dios y clasificarlo con una etiqueta (aunque sea buena) puede que se trate del pecado más terrible en sus manos. El creyente para ser tal debe creer en Dios sin condiciones, éste es el germen de la verdadera fe.

Los propios textos religiosos reflejan un Dios ambivalente que contiene un lado oscuro. Así, el Dios de la zarza que se presenta ante Moisés en su imagen de facies bicornuta, mata al que le sostiene la mirada (Exodo, 33: 20, 34: 29) y manda a los hijos de Leví a matar cada uno a su hermano, a su amigo y a su pariente (Exodo, 32: 2527). El Dios del sueño de Jacob le hace exclamar (Génesis, 28:17): «iQué temible es este lugar! ¡Esto no es otra cosa sino la casa de Dios y la puerta del cielo!» (al estilo del «jel horror!, jel horror!» de Joseph Conrad); ${ }^{32}$ en Números (22:22) aparece la figura del «mal'āk Jahwe» como ángel retador que se opone a Balam; ${ }^{33}$ y el Dios de la tormenta del Libro de Job hace callar a éste imponiendo su poder (Job, 38-42), por poner

\footnotetext{
${ }^{30}$ M. J. Lerner, The Belief in a Just World: A Fundamental Delusion, Plenum Press, New York-London, 1980, esp. pp. 6-26.

${ }^{31}$ Sobre los datos de España, vid. datos INE publicados el 30 de abril de 2010 en http://www.ine.es/inebmenu /mnu salud.htm.

${ }^{32}$ J. Conrad, El corazón de las tinieblas (trad. A. García Ríos e I. Sánchez Araujo), Alianza, Madrid, 1997.

${ }^{33}$ Cfr. R. Schärf, «La figura de Satanás en el Antiguo Testamento», en C.G. Jung Simbología del espíritu. Estudios sobre fenomenología psíquica (trad. M. Rodríguez Cabo), Fondo de Cultura Económica, Madrid, 1998, 1998, pp. 113-228, p. 159
} 
sólo unos ejemplos. Incluso el profeta Isaías proclama oficialmente un Dios dual y ambivalente: «Yo soy Yahvé, no hay ningún otro; yo modelo la luz y creo la tiniebla, yo hago la dicha y creo la desgracia, yo soy Yahvé el que hago todo esto» (Isaías, 45: 6,7). Todo ello se relaciona asimismo con el concepto de sagrado y de lo numinoso que ya analizara en profundidad R. Otto, en Lo santo, consciente de que tocaba algo misterioso y probablemente la esencia de todas las cosas. ${ }^{34}$ Para R. Otto (Ibid, p. 3) lo demoníaco y el pavor demoníaco forman parte de lo numinoso, en su categoría del tremendum, como su grado inferior de desarrollo o estadio (caos) primigenio. De esta manera, como dos líneas paralelas se acaban juntando en el infinito, el bien y el mal aunque aparezcan de forma separada tenderían a unirse en algún punto del ser-Dios.

No obstante, paradójicamente el único argumento sólido de la teodicea sería que el mismo mal que sirve para poner en cuestión la existencia a priori de un Dios (bueno) nos puede llevar a justificar a posteriori su existencia. Si la persistencia del mal pone en cuestión la bondad de Dios, la persistencia del ser humano «a pesar del mal» dificulta que pueda hablarse de una humanidad sin Dios, pues ¿cómo puede entenderse que el ser humano no se haya destruido todavía a sí mismo (guerras, conflictos) o la naturaleza (epidemias, sequías, glaciación, choque de asteroides, etc...) lo haya hecho en su lugar sin un alguien-algo que nos proteja?

\subsection{TODOS NACEMOS LIBRES E IGUALES; EL MAL ES NECESARIO PARA LA LIBERTAD HUMANA Y POR TANTO PARA SU DIGNIDAD}

Por el contrario sostenemos que «no somos iguales frente al mal y no nacemos libres, nacemos incompletos, nos hacemos libres con esfuerzo».

\section{a) ¿Somos esencialmente iguales?}

No se trata de poner en cuestión el artículo 1 de la Declaración universal de Derechos humanos: «Todos los seres humanos nacen libres e iguales en dignidad y derechos (...)». Podemos/debemos ser iguales frente a la ley pero lo cierto es que no somos iguales frente al mal: «Después de todo hay algo en el mundo que permite que un hombre robe un caballo mientras otro ni siquiera puede mirar un ronzal» (J. Conrad, o.c., p. 60). No es que las diferencias se den entre mujeres y hombres, o negros y blancos, sino que dentro de cada uno de esos grupos en función de su carácter y su posición los individuos se comportan de forma diferente frente al mal. ${ }^{35}$ Desde el campo

\footnotetext{
${ }^{34}$ R. Otto, Lo santo. Lo racional y lo irracional en la idea de Dios (trad. F. Vela), Alianza, Madrid, 1980. Estos conceptos R. Otto los matiza y amplía en su libro: Ensayos sobre lo numinoso (trad. M. Abella), Trotta, Madrid, 2009. Ver también sobre esta cuestión en esta misma revista: J.L Cardero López, «De lo Numinoso, a lo Sagrado y lo Religioso (Magische Flucht, Vuelo Mágico y éxtasis como experiencias de lo Sagrado)», 'Ilu. Revista de Ciencias de las Religiones, 2009, 14, pp. 215-229, donde se exploran los contornos y diferencias de esos tres conceptos.

${ }^{35}$ Philip Zimbardo, profesor emérito de psicología de la universidad de Stanford, dirigió a principios de los años setenta un experimento conocido como la «prisión de Stanford» donde estudiantes y voluntarios
} 
de la psicología del lenguaje, Steven Pinker ha defendido que el ser humano es un organismo biológico y que como tal nace «programado» en muchos aspectos de su carácter y capacidades, lo que hace que algunas personas puedan estar mejor dotadas y otras hayan podido nacer con una predisposición especial a la violencia. ${ }^{36}$

\section{b) Sobre la libertad}

Otra de las ideas pre-concebidas que dominan el discurso sobre el mal es que éste resulta una condición para que el ser humano pueda elegir (aunque el libre albedrío no justifique el mal-sufrimiento de los animales), lo que va unido a la presunción de que «o el ser humano es libre o simplemente no es digno de tal nombre» que encontramos, por ejemplo, en Fichte y en S. Agustín. Sin embargo, para que podamos hablar de libertad no resulta imprescindible que exista en concreto el mal sino un mínimo número de opciones, que pueden incluir o no al mal (es decir podrían ser todas más o menos buenas según para qué). Lo que sí resulta imprescindible sin embargo es disponer de un mínimo grado de conocimiento que permita al que elige saber qué es lo que más le conviene.

El objetivo común tanto a la teología como a la filosofía más racionalista ha sido otorgar al ser humano una dignidad de partida, bien obtenida por linaje -nada menos que ser hijos de Dios- o por bagaje evolutivo -donde llega a reemplazar a Dios convirtiéndose así en el único ser «inteligente» del universo-. Hay una libertad externa, la del art. 3 de la Declaración de Derechos humanos: «Nadie estará sometido a esclavitud ni a servidumbre»; otra cosa es la libertad interna. Por tanto cabe diferenciar entre acto libre y acto voluntario (que no resulta de coacción ajena); éste último es el que determina nuestro grado de responsabilidad ética. Existe, no obstante, la presunción que nosotros nos movemos por decisiones racionales o por emociones claramente identificadas (ira, amor, magnanimidad), pero lo cierto es que de ese algo que nos mueve en realidad no se sabe casi nada. ${ }^{37} \mathrm{El}$ ser humano se mueve, por una parte, entre la obsesión por ser libre y el miedo a la libertad (E. Fromm) y, por otra, condicionado por su carácter, al que podemos definir como «el conjunto de las disposiciones que sistemáticamente le llevan a actuar de un modo antes que de otro, a llevar una determina-

representaron durante algunos días los papeles de prisionero y carceleros, sufriendo transformaciones de carácter impresionantes en la mayoría de los casos. De esta experiencia se sacó un patrón de cambio de comportamiento que comienza por la deshumanización del antes amigo-amable vecino y ahora tenido por adversario, lo que se dio tanto en el nazismo como en varias guerras civiles más recientes (la exYugoslavia y Ruanda la de tutsis y hutus, en todos estos casos con violaciones masivas) e incluso en la prisión de Abu Ghraib durante la ocupación de Irak. Su conclusión fue que personas normales y tomadas por buenos ciudadanos pueden transformarse rápidamente en verdaderos demonios cuando se dan determinadas circunstancias situacionales y actúan bajo sistemas concretos: «el poder sutil pero penetrante de una multitud de variables situacionales puede imponerse a la voluntad de resistirse a esa influencia» [P. Zimbardo, El efecto Lucifer: el porqué de la maldad (trad. G. Sánchez Barberan), Paidós, Barcelona, 2008, p. 19]. Ahora bien, el estudio de Zimbardo también demuestra que no todas las personas reaccionan de la misma manera, que siempre hay una minoría, a los que no duda de calificar como héroes y heroínas, que consiguen resistirse a la influencia del ambiente (Ibid. p. 567).

${ }^{36}$ S. Pinker, The Stuff of Thought: language as a Window into Human Nature, Viking, New York, 2007.

${ }^{37}$ Cfr. Jacobi, citado por G. Albiac en B. Spinoza, op. cit. nota 1, p. 66. 
da clase de vida». ${ }^{38}$ El problema estribaría en saber si el ser humano es libre para elegir esa personalidad o carácter que está al mismo tiempo contribuyendo de manera directa a limitar su ámbito de actuación potencialmente libre. ${ }^{39}$ En este sentido, para B. Spinoza nada existe sin causa que lo determine (op. cit., parte I, axioma III) por lo que añade (adelantándose a Freud) que: «los hombres se imaginan ser libres puesto que son conscientes de sus voliciones y de su apetito, y ni soñando piensan en las causas que les disponen a apetecer y querer, porque las ignoran» (Ibid., I, apéndice, p. 113).

Como consecuencia, la idea del «hombre libre» constituye una imagen pre-concebida que contamina cualquier intento de descubrir la verdadera naturaleza del ser humano. De hecho, teniendo en cuenta los últimos descubrimientos de la neurociencia sobre el funcionamiento del cerebro, las propias características biológicas de la libertad parecen estar en cuestión pues la toma de conciencia de una decisión a nivel cerebral es posterior al envío químico de la correspondiente orden. ${ }^{40} \mathrm{Y}$ si no sabemos muy bien cómo se fabrican nuestras ideas, ¿cómo podemos estar seguros de que son nuestras? Contra ese modelo cabe sostener que la dignidad el ser humano debe ganársela con su esfuerzo y coraje para enfrentarse al mal y sus propias limitaciones, esta vez sí, incluidas en su paquete de llegada a este mundo. Aunque la libertad no sea necesariamente un punto de partida sí puede ser un punto de llegada o, parafraseando a Hegel, la libertad más que supuesto es conquista. Menos las leyes de la naturaleza, el resto de condiciones son susceptibles de ser «manejadas» con esfuerzo, voluntad y conocimiento (y algo de suerte).

Por tanto el ser humano no nace necesariamente libre, pero es el único animal que nace con la posibilidad de llegar a ser libre, si bien debe ganarse la dignidad con esfuerzo y coraje al enfrentarse al mal y sus propias limitaciones. Es decir, nace incompleto, está aquí para completarse y no resulta responsable del nacimiento del mal en el mundo pero sí co-responsable de su mantenimiento. Cuanto antes reconozcamos este hecho antes podremos enfrentarnos a él pues ¡flaco favor le haríamos a la libertad al darla por supuesta!

\section{4. ¿QUÉ HACER CON EL MAL? FRENTE A LA JUSTIFICACIÓN, LA LUCHA RELACIONAL-INTEGRAL}

\subsection{AL MAL SE LE PUEDE Y SE LE DEBE JUSTIFICAR O SÓLO CABE RESIGNARSE}

Por el contrario, sostenemos que «quien justifica al mal se convierte en su cómplice pues le ofrece una coartada para que sobreviva. Contra el mal hay que luchar como única opción verdaderamente moral». Fue probablemente Maquiavelo uno de

\footnotetext{
${ }^{38}$ A. MacIntyre, Tras la virtud (trad. A. Valcárcel), Crítica, Barcelona, 1987, p. 59.

${ }^{39}$ A. Gil Ibáñez y y J.L Cardero López, «La guerra de los caracteres: la madre de todas las batallas» Revista de Antropología Experimental (Universidad de Jaén), 2003 II, nº3 (www.ujaen.es/huesped/rae), pp. 41-48.

${ }^{40}$ F.J. Rubia, El fantasma de la libertad. Datos de la revolución neurocientífica, Crítica, Barcelona, 2009.
} 
los que más claramente vino a justificar la bondad (y utilidad) del mal si éste era puesto al servicio de una «buena» causa, aunque ésta fuera la garantizar la supervivencia del Estado. ${ }^{41}$ Leibniz, por su parte defendió que el mal era un elemento necesario para estar en el mejor de los mundos posibles, éste en el que vivimos. ${ }^{42}$ Pero sin necesidad de citar a Voltaire y su Cándido, podemos afirmar que éste no es el mejor mundo que pueda existir, es simplemente el único que conocemos.

Hay, no obstante, una oferta variada de justificaciones al uso: es necesario que exista el mal para que se dé el bien, es algo inherente a la misma realidad, «no hay mal que por bien no venga», etc... Sin embargo, mientras la posibilidad de un mundo compuesto sólo de mal se revela imposible (pues se destruiría a sí mismo), la de una realidad compuesta por diversas tonalidades del bien parece claramente factible. También se ha dicho que el mal es necesario como forjador de carácter y de la virtud pues ésta requiere «contrastes y dificultades y necesidad de que no pueda ejercerse sin contraposición» ${ }^{43}$ Sin embargo, a una hija violada repetidamente por su padre (Josef Fritzl, «monstruo de Amstetten») durante más de veinte años, encerrada en un cuarto oscuro en el sótano de la casa familiar con la puerta tapiada y que ve como le nacen siete hijos-hermanos, alguno de ellos asesinado al poco de nacer ¿realmente podemos decirle que su mal estaba justificado?, ¿que es una puerta al aprendizaje o para la mejora personal?, ¿que es el precio de su libertad? Y es que estos casos tampoco pueden ser ignorados considerándolos anecdóticos o extraordinariamente excepcionales.

La justificación del mal siempre esconde algún interés oculto (defender a un Dios bueno, sostener un determinado concepto «maravilloso» de la vida, de un sistema político o del Estado ...) que nos lleva finalmente a la melancolía. Con el mal no sirven excusas. Por ello planteamos la lucha interna y externa (en el interior y el exterior del individuo) como única opción moral, una ética en torno al deber de luchar contra el mal-exceso, la única posible entre sujetos con diversas creencias y no-creencias. Consideramos a la lucha como bien en sí y como camino de transformación del individuo y de la realidad, más allá de que finalmente se tenga éxito (total) o no. Los problemas complejos difícilmente tienen soluciones completamente satisfactorias por lo que hay que acudir a soluciones no óptimas, si bien aunque no podemos esperar que el mal desaparezca del todo, sí podemos pretender que disminuya su poder y presencia.

No hay que justificar el mal pero sí reconocer su existencia y aceptarlo -dentro de una mirada ecuánime de la realidad- como prerrequisito para la lucha. Pretender «escapar» de la cuota de sufrimiento que entraña el estar vivo es la receta más segu-

${ }^{41}$ N. Maquiavelo, El Príncipe (trad. A. Zozaya), Dirección y Administración (E1 Liberal), Madrid, 1887: «no debe cuidarse el príncipe de incurrir en la maldad si ésta encamina al bien público» (p. 9). Cita igualmente a Agatocles y Oliveretto (o el papa Alejandro VI que no hizo otra cosa sino engañar a los hombres, p. 104) como ejemplos de hombres crueles e incluso inhumanos, pero a los que debe considerarse ilustres y eficaces gobernantes por su valor y virtud para vencer y superar los peligros y soportar y superar lo adverso pues la crueldad no es un mal en sí sino en función del uso que se haga de ella (pp. 56 y 58, 59, 72).

${ }^{42}$ G.W. Leibniz, Discurso de metafisica (trad. J. Marías), Alianza, Madrid, 1981.

${ }^{43}$ M. de Montaigne, Ensayos completos (trad. J. G. de Luaces), Ediciones Omega, Barcelona, 2002, Libro II, Ensayo XI, p. 341. 
ra para acabar en la pura indolencia, la depresión o cualquier otro tipo de enfermedad mental. ${ }^{44}$ Hay una estrategia que está presente tanto en la mística, como en la teología y en la propia filosofía: al sufrimiento hay que aceptarlo como parte de la vida (la «santa indiferencia»), usándolo como trampolín para la recuperación personal. Pero ¿basta sentarse a esperar algún acontecimiento milenarista o apocalíptico o a que el destino cumpla su función? El mayor obstáculo para comenzar a ganar la batalla al mal es pensar que la victoria es imposible, a lo que contribuye el justificarlo. Específicamente sobre la lucha el Bhagavad-Gita (capítulo XVIII) dice: «[T]ú dices, guiado por tu egoísmo: 'No quiero luchar'; pero tu decisión es inútil, pues este combate te es ordenado por tu propia naturaleza». La renuncia a la lucha sólo puede venir del ego que incita a la pereza o a la confusión pues es voluntad del Supremo que luchemos por lo que escapar a la lucha puede considerarse como un retraso de nuestro destino inapelable. ${ }^{45}$

El ser humano debe pasar a la acción, entre otras razones, porque sólo así puede vencer a uno de los mayores peligros del mal: quedarse en la obsesión, en la confusión o pensamiento circular-autoreferencial. La acción nos lleva a ponernos al mando de las riendas de nuestra vida y para esta tarea la figura del héroe (a pesar de los que la declaran obsoleta) sigue resultando universal (aparece en todas las culturas y todos los tiempos) y psicológicamente útil. ${ }^{46}$

\subsection{FRENTE AL MAL, SÓLO CABE OPONER EL BIEN O LA INTEGRACIÓN DE OPUESTOS}

Sostenemos como alternativa que «contra el mal, hay que aplicar una estrategia global y unitaria, utilizando todos los medios y armas disponibles, incluido el propio mal». Luchar, sí, pero ¿cómo? Cabría calificar sin duda de imprudente al general que enfrentado a un enemigo superior en armas y número renunciara a parte de sus tropas (p. ej. por ser creyentes o no creyentes) o herramientas. El ser humano que acepta la lucha debe ser capaz de enfrentarse a lo que se esconde tras la verdad del mundo y de sí mismo (las zonas oscuras de su psique), lo que no tiene necesariamente por qué ser agradable: «El héroe, ya sea dios o diosa, hombre o mujer, la figura en el mito o la persona que sueña, descubre y asimila su opuesto (su propio ser insospechado) ya sea tragándoselo o siendo tragado por él» (J. Campbell, op cit. p. 103). Una de las principales aportaciones de Freud consistió precisamente en resaltar el miedo que existe al conocimiento de uno mismo, de las propias emociones, impulsos, aptitudes, miedo que se convierte asimismo en temor al mundo. Señala J. Campbell que «la primera misión

\footnotetext{
${ }^{44}$ M. Scott Peck, «La curación del mal humano» en C. Zweig y J. Abrams (eds.), Encuentro con la sombra: el poder del lado oscuro de la naturaleza humana (trad. D. González y F. Mora), Kairós, Barcelona, 2004 ( $9^{\text {a }}$ ed.), pp. 252-260, p. 259.

${ }^{45}$ Shri Aurobindo, La Bhagavad-Gîtâ (trad. C. Rao y J. Herbert), Albin Michel, París, 1970, pp. 59, 61, 66, 321.

${ }^{46}$ J. Campbell, El héroe de las mil caras. Psicoanálisis del mito (trad. L. J. Hernández), Fondo de Cultura Económica, México, 1959.
} 
del héroe es retirarse de la escena del mundo de los efectos secundarios, a aquellas zonas causales de la psique que es donde residen las verdaderas dificultades, y allí aclarar dichas dificultades, borrarlas según cada caso particular (o sea, presentar combate a los demonios infantiles de cada cultura local) y llegar hacia la experiencia y la asimilación no distorsionada (...)» (Ibid., p. 24). Sólo cuando seamos capaces de comprender, integrar y hasta amar nuestra propia sombra seremos capaces de hacer lo mismo con la sombra de Dios, lo que constituye el germen de la verdadera fe. Ahora bien, para ello se requiere preparación pues tal vez, tras el desconocimiento o ignorancia de lo que somos o de la realidad que nos rodea se esconda una «protección» de algo que tememos conocer porque probablemente desvelarlo nos destruiría.

El héroe requiere también enfrentarse al mundo exterior con humor, amor, pero sobre todo valor: «Eran lo bastante hombres como para afrontar las tinieblas». ${ }^{47}$ Luchar contra el mal parece una tarea fácil cuando las cosas nos van «bien» (es decir cuando el mal está oculto o no se hace presente), pero el sentido de la lucha es precisamente poder continuar dando la batalla cuando las cosas peor se ponen, es decir aprender a navegar con el viento en contra. Por otra parte, para la lucha contra el mal más que exigentes votos o grandes ascesis, lo que resulta imprescindible es el «compromiso de mesura» pues un exceso de optimismo, como de pesimismo, puede resultar igualmente devastador. De nuevo el bien nos lleva a optar por la sensatez y el equilibrio, que no debe confundirse con pasividad o laxitud sino con la idea de «mitad», de encontrarse en el medio.

Por último, cuando todo esto falla no hay más remedio que oponer el mal frente al mal. Esta utilización paradójica la aprendemos de la historia (para frenar a Hitler) pero también de los textos religiosos, donde se plantea la necesidad de operar con mente no-egóica y purificarse después (Baghavad-Gita y mitos mesopotámicos y ugaríticos). También, en algunas versiones del zoroastrismo el «hombre primordial» acaba devorado en su lucha con el demonio, pero esa muerte es voluntaria ofrecida como sacrificio para que una vez dentro de la oscuridad (es decir «bajando a los infiernos»), la propia naturaleza del alma del «hombre primordial» reviva y se mezcle con la naturaleza de la propia oscuridad que quedaría así neutralizada (los paralelismos con la figura de Jesucristo son evidentes). Es decir, el bien se hace mal para desde dentro poder acabar con él, una astucia en definitiva (como complemento de la mansedumbre, nos dicen los evangelios) puesta al servicio de la lucha. Esto no implica justificar el mal sino utilizarlo, como último remedio, en la medida que sigue estando todavía ahí.

\subsection{FRENTE AL MAL, LLEGADO EL CASO, NOS QUEDA EL MISTERIO O LA CIENCIA-RAZÓN}

Frente a ello sostenemos que «hace falta un nuevo modo de acercarse al saber: un enfoque relacional-integral y una razón ampliada».

\footnotetext{
${ }^{47}$ J. Conrad, op. cit., p. 25. El término «hombres» lo tomamos aquí como sinónimo de «valor y coraje» y no del género masculino.
} 


\section{a) Sobre la razón ampliada}

Frente al mal excesivo se ha dicho que el creyente mira a Dios y se queda sin respuestas restándole sólo el misterio. ${ }^{48}$ Pero éste se convierte en exceso (mal) cuando sirve de coartada para la pasividad o para dejar de preguntarnos pues el ser humano necesita saber aunque siempre esté en camino. Por otra parte, frente al paradigma de que «la razón lo puede todo» cabe defender que «hoy por hoy, la razón no lo puede todo y nadie ni nada sobran en la lucha contra el mal». La cuestión es si el ser humano puede con su sola razón, acceder y alcanzar todo el conocimiento y comprender las últimas verdades o si para ello en todo o en parte requiere de otro tipo de instrumentos cognitivos, como la intuición, la imaginación creativa, las emociones, la poesía, la meditación, la iluminación, la revelación o la propia fe. ${ }^{49}$ Nos guste o no el conocimiento (exclusivamente) racional no resuelve todos nuestros problemas, al menos no los más profundos (emocionales) ni los más fundamentales (aunque sean científicos). Si nos limitáramos exclusivamente a fiarnos de lo que ven nuestros ojos y tocan nuestras manos, no hubiéramos cruzado el océano para confirmar el carácter esférico de nuestro planeta ni hubiéramos llegado a plantear la realidad cuántica sub-atómica.

Muchos científicos y filósofos han reconocido que resolvieron intrincados problemas matemáticos o científicos gracias a un momento de «inspiración». René Descartes tuvo un sueño que le puso de manifiesto que la conquista de la naturaleza iba a conseguirse mediante la medida y los números; a Kekulé, el descubridor del anillo de benceno, en otro sueño se le mostró el símbolo urobórico como la solución para un problema de estructura molecular. ${ }^{50} \mathrm{~A}$. Einstein dijo que su descubrimiento esencial de la teoría general de la relatividad llegó cuando al levantarse una mañana «vio de repente» la idea, y alabó en varias ocasiones a la intuición como método insalvable para llegar a descubrir varias leyes físicas ya que aunque los axiomas se apoyan en experiencias «no existe ningún camino lógico que conduzca de la experiencia a los axiomas, sino sólo una conexión intuitiva». ${ }^{51}$ Carl Gauss y Henri Poincaré dieron solución a ciertos complejos problemas matemáticos de forma inesperada sin un previo razonamiento del que trajeran causa, y algunos científicos comparten la visión platónica de que las fórmulas matemáticas tiene una existencia previa e independiente de la mente humana y son en potencia «directamente» accesibles sin un razonamiento que las preceda. ${ }^{52}$

El propio método científico (sin negar sus formidables aportaciones) muestra sus limitaciones. Dependemos de lo que podemos observar, y no siempre nos resulta fácil observarnos desde fuera, como un agente imparcial. Es más, el saber científico «de-

\footnotetext{
48 J. Hick, Evil and the God of Love, Collins, Norfolk, 1975 (4 imp., $1^{\mathrm{a}}$ ed. 1968), p. 370.

49 «La fe comienza donde la razón termina», diría S. Kierkegaard, 1975, Temor y Temblor (trad. V. Simón. Merchán), ed. Nacional, Madrid, 1975, 120.

${ }^{50}$ Ejemplos tomados de: R. Sheldrake, T. McKenna, R. Abraham, Caos, Creatividad y Conciencia Cósmica (trad. L. Pascual Gargallo), ed. Ellago Ediciones, Castellón, 2005, p. 139.

${ }^{51}$ Citado por A.G. Gargani, «La experiencia religiosa como acontecimiento y representación» (trad. A. Abellán) en J. Derrida y G. Vattimo (eds.), La religión, PPC, Madrid, 1996, pp 179-197, 182 y 183.

${ }^{52}$ Cfr. J. Hadamard, Psicología de la invención en el campo matemático (trad. L.A. Santaló Sors), Espasa Calpe, Buenos Aires, 194, pp.14ss.
} 
pende» (aunque le cueste reconocerlo en ocasiones) de los sentidos (limitados y falibles) del experimentador, una experimentación centrada en el mundo de tres dimensiones y a un número de ensayos o descubrimientos asimismo limitados, una razónlógica (condicionada por un cerebro finito y tridimensional) y un razonamiento matemático cuya validez se tambalea cuando se enfrenta al infinito. Como ya reconociera F. Bacon, uno de los fundadores del pensamiento científico, la ciencia puede combatir las ilusiones o ídolos artificiales que bloquean o confunden la mente humana (derivados de doctrinas filosóficas o de perversas reglas de prueba), pero de ninguna manera los innatos, consecuencia de la permanente tendencia al error y el carácter limitado del mismo intelecto. ${ }^{53} \mathrm{Y}$ sin embargo, su aspiración es explicar «el todo» a pesar de que la propia ciencia admita que existen bastantes más de tres dimensiones, donde la realidad podría comportarse de otras maneras. ${ }^{54} \mathrm{La}$ ciencia mantiene una relación ambivalente con el ámbito de lo desconocido pues mientras permanentemente se dedica a negarlo, permanente se dedica a revelarlo. De hecho, cuando la explicación de un fenómeno es excesivamente compleja normalmente se debe a que se esconden aspectos que se nos escapan o que no se comprenden del todo.

Todo esto obviamente no le quita valor al enfoque científico pero lo «humaniza», lo saca del endiosamiento en el que lo coloca la vanidad excesiva de algunos de sus «sacerdotes». De acuerdo con esta aproximación más realista y humilde resulta «irracional» renunciar de antemano a completar los instrumentos racionales stricto sensu con otros, tal vez no menos falibles, pero que nos ayudan a superar nuestros límites y a abrir nuevos horizontes con objeto de acercarnos a ese proceso continuo y latente que se esconde tras la realidad visible a los sentidos y que permanentemente escapa a nuestra capacidad de observación racional (cfr. F. Bacon, The New..., op. cit., p. 106), o a ese orden implicado del que nos habla D. Bohm (op. cit.). En definitiva, nuestra razón es un instrumento sin duda valioso y sofisticado de aproximación a la realidad, pero no necesariamente único ni perfecto ni el más completo que pueda hipotéticamente existir.

\section{b) Sobre el método relacional-integral}

La verdad es una cuestión que se nos presenta siempre esquiva y más si dividimos nuestros esfuerzos, compartimentalizando el saber. Si aceptamos que hay varios saberes incomunicados entre sí deberíamos forzosamente también reconocer que existen varias verdades. ¿Es esto lo que reclama nuestro sentido común? Otra cosa es

\footnotetext{
${ }^{53}$ F. Bacon, The New Organon, op. cit. pp. 18 y 40 (aforismo XXXIX). Esto llevaría a tener que aceptar el conocimiento inherentemente limitado del conocimiento del ser humano pues éste sólo puede comprender lo que es capaz de observar del orden natural directamente o por inferencia y no puede hacer nada más (Ibid., p. 33, Aforismo I) y es que aunque admiremos los poderes de la mente humana desconocemos todavía cuáles son sus fundamentos reales (Ibid., p. 34, aforismo IX). Afirmaciones que siguen vigentes hoy.

${ }^{54}$ Un ejemplo reciente lo constituye el «descubrimiento» de una bacteria que puede crecer utilizando arsénico en ligar de fósforo, alterando el «dogma» científico (irracional) de que toda forma posible de vida tenía que ser necesariamente como nosotros y demostrando que la vida puede ser mucho más flexible de lo que algunos pensaban (vid. F. Wolfe-Simon et alt, «A Bacterium That Can Grow by Using Arsenic Instead of Phosphorus», publicado el 2 de diciembre de 2010 en http:www.sciencemag.org).
} 
que sea complicado alcanzar una verdad fija por parte del ser humano pues si la verdad cabe definirla como una relación fija e indestructible entre lo exterior y lo interior al ser humano difícilmente puede hablarse de verdad accesible cuando los dos términos de esa relación están lejos de estar fijos, claros o ser unívocos. ${ }^{55}$ Nos encontramos frente a un conocimiento móvil en permanente evolución, donde importa no sólo la dirección sino los motores del movimiento.

El objetivo del saber debe ser por tanto profundizar y elevar de manera permanente el nivel de discusión, aspirando así a ser el antídoto de la ignorancia y el engaño como dos vertientes del mal. A este respecto, el pensamiento relacional-integral es el instrumento de una razón ampliada no dividida. Frente al mal y la ambivalencia sólo cabe relacionar e integrar. Para ello todas las formas de acceso al saber deben tener en cuenta que persiguen una verdad que necesariamente es única, acercarse a lo profundo de lo real y atreverse a descender a los infiernos para enfrentarse al mal, si pretenden ser útiles al ser humano. No se trata de negar la necesidad de profundizar en el conocimiento de algo (movimiento vertical), sino de mostrar que ese enfoque debe ser combinado con otro en sentido horizontal, de relacionar lo aprendido con otras ramas del saber, donde el objeto de la investigación queda igualmente afectado, pero desde otro punto de vista, desde otro lado. En este sentido, cabe definir el saber relacional como el intento permanente, evolutivo y no estático de alcanzar la verdad, tanto la del mundo visible a nuestros sentidos como la de «lo absolutamente otro», que se da a través de la relación, tanto por medios sofisticados como ordinarios, entre el camino religioso, filosófico, científico, todo ello con el objetivo final de eliminar al mal de nuestras vidas y del mundo. Como en democracia parece asentado que existen tres poderes que ejercen de contrapeso entre sí porque cada uno dejado a su libre desarrollo acabaría en el exceso, así existen tres saberes, cada uno controlando a los otros, y con los estudios de la mente humana ejerciendo de verdadero tribunal constitucional por si hemos entrado en el puro desvarío o locura. Precisamente el enfoque relacional-integral y la aceptación de una realidad ambivalente permiten encontrar un camino intermedio entre el dogmatismo y el relativismo, convertido éste último en un absoluto que se niega a sí mismo (si todo es relativo esto también debe serlo).

Para llevar a cabo esta relación-integración proponemos cuatro criterios: a) la ciencia marca el límite del conocimiento racional, pero no puede amordazar a otros tipos de conocimiento; b) frente a lo que permanece como desconocido, se impone la humilde reverencia frente al misterio, religión, filosofía y ciencia deben cooperar, si bien aquí, la religión puede ofrecer las imágenes y mitos más sugerentes; c) el papel de la filosofía y la psicología (como representante de los estudios de la mente) debe ser el de controlador y árbitro, puente entre lo conocido y lo desconocido, entre el dominio de la ciencia y el dominio de la religión, para impedir abandonar el territorio innegociable del sentido común y de la dignidad del ser humano; d) nunca debe olvidarse que el objetivo final de todo saber es la lucha contra el mal. De hecho, tomar la lucha

${ }^{55}$ E. Cassirer, El problema del conocimiento en la filosofia y en las ciencias moderna, Vol I (trad. W. Roces), Fondo de Cultura Económica, México, 1974 (2ª reimp., 1ª ed. 1953), p. 202. 
contra el mal como objetivo común y prioritario es un requisito para que exista y se dé la «comunicación» entre disciplinas diversas e incluso entre personas. Es lo que le falta a la «Teoría de la comunicación» porque cuando los objetivos de los sujetos se fundamentan en su propia vanidad u objetivo parcial e interesado, el resultado es que hablan lenguas distintas (aunque compartan la misma materna) y que la torre para alcanzar «el cielo» del conocimiento nunca será construida; es lo que podemos denominar «paradigma anti-Babel».

La separación y hasta enfrentamiento entre religión, ciencia y filosofía parece clara y hasta necesaria cuando nos quedamos en un conocimiento superficial de las cosas, sin embargo cuando el filósofo, el científico o el religioso superan el mundo de las formas y profundizan «suficientemente» en el enigma de la realidad, aparece el misterio, el absurdo, la intuición, lo infinito o lo absoluto, etc..., y entonces los tres hablan de lo mismo aunque utilicen distintas palabras. Esta integración de saberes se facilita si se va «a lo hondo» de las cosas, del pensamiento y del espíritu, para ver «su raíz» pues es ahí donde las «ramas» del conocimiento se encuentran: mística (religión), metafísica (filosofía) y física cuántica (ciencia). Y junto a ellas la psicología y demás disciplinas (psiquiatría, neurobiología, etc...) que profundizan en el estudio de la mente. Así, por ejemplo, desde William James (op. cit.) han sido muchos los que se han interesado por la relación entre psicología y religión (¿cabría hablar de una psicología de la religión?), si bien mientras la psicología identifica (en su caso) el mal como una parte más de la mente del individuo, la religión admite que existen fuerzas más allá del individuo que pueden estar detrás de actos malvados, sin que ello implique dejar de tener al propio individuo y a su mente como responsables del mal pues al fin y la cabo el diablo no podría ejercer la mayor parte del mal sin la complicidad y participación del ser humano. ${ }^{56}$ En todo caso, dos áreas de comunicación potencialmente fructíferas en este ámbito serían la experiencia mística y el ritual de exorcismo, no tanto porque haya poseídos o no, sino porque en determinados casos se ha demostrado su eficacia.

\section{EN CONCLUSIÓN: ¿HACIA UN NUEVO PARADIGMA?}

El saber occidental no ha interiorizado ni deducido todavía todas las consecuencias necesarias del descubrimiento del papel del inconsciente y de la naturaleza cuántica de la realidad. Sabemos que un mundo se está derrumbado, pero nos da miedo reconocerlo y nos mostramos incapaces de construir uno nuevo en su lugar porque en ello va en juego nuestro propio equilibrio psicológico fundamentado frágilmente sobre un determinado concepto del ser humano, de Dios (o de lo que se esconde tras esta palabra para los ateos) y del mundo: una trinidad ambivalente.

Contra el discurso dominante pero fallido cabe plantear un nuevo paradigma que reconoce que el mal existe y tiene una entidad propia que toma cuerpo en el exceso.

\footnotetext{
${ }^{56}$ Cfr. padre Amorth, citado por J.A. Sayés, El demonio ¿realidad o mito?, EDICEP C.B., Valencia, 2008, p. 139.
} 
A este mal sólo cabe plantarle cara como única opción moral humana, luchando con todas las armas disponibles pues en caso contrario nos queda caer en la banalidad, la melancolía o el puro esperpento. Para este combate ético se requiere una huída de los extremos, una astuta combinación de bien y mal, y un saber relacional-integral que tome la lucha contra el mal como su primer objetivo, que siempre persiga su derrota aunque difícilmente pueda alcanzarse su total eliminación o transformación. Otra cosa es que como fruto de la lucha el mal puede dejar de existir como tal, al menos para el que ha luchado con la cabeza alta y el corazón abierto. Todo ello sin rechazar la ambivalencia que forma parte de la realidad, pero que no cuestiona su existencia, como señala este haiku:

«Mientras el mal se hace presente, en medio de la quietud de la noche una nuez cae al lago y hace ipok!» 